\title{
Cattle Dung Breeding Diptera in Pastures in Southeastern Brazil: Diversity, Abundance and Seasonallity
}

\author{
Júlio Mendes, Arício Xavier Linhares*/+ \\ Departamento de Patologia, Universidade Federal de Uberlândia, Uberlândia, MG, Brasil *Departamento de Parasitologia, IB, \\ Universidade Estadual de Campinas, Caixa Postal 6109, 13083-970 Campinas, SP, Brasil
}

Diptera that breed in undisturbed cattle droppings in pastures present great diversity and abundance, and several species are of veterinary importance and may cause economic losses. To survey the diversity, abundance and seasonality of Diptera associated to this microhabitat, 83 samples of 10 dung pats each were taken from April 1992 to April 1994 in the vicinity of São Carlos, State of São Paulo, Southeastern Brazil. A total of 46,135 Diptera belonging to 20 families and at least 51 species were found to breed in the pats. The most abundant and diverse families were Sepsidae, Muscidae, Sarcophagidae and Sphaeroceridae. In general, the abundance was higher from October to March, the warm and wet months. The importance of some Diptera, both as horn fly enemies and as cattle dung decaying agents, is discussed.

Key words: Diptera - cattle dung - dung flies - diversity - seasonality - Brazil

Cattle dung pats naturally dropped in pastures are the microhabitat for an abundant and diversified arthropod fauna (Merrit \& Anderson 1977, Anderson et al. 1984, Blume 1985, Cervenka \& Moon 1991). The coprophagous community is represented mainly by Scarabaeidae (Coleoptera) and Diptera that are the most important decaying agents of the dung pats (Laurence 1955, Nibaruta 1982, Anderson et al. 1984, Cervenka \& Moon 1991). Dung breeding Diptera are generally the most diverse group in cattle dung pats (Poorbaugh et al. 1968, Nibaruta 1982, Blume 1985, Cervenka \& Moon 1991), and several species, such as the face fly Musca autumnalis (De Geer 1776) and Haematobia spp. (Diptera: Muscidae) are of veterinary importance (Lancaster \& Meish 1986).

The recent introduction of the horn fly Haematobia irritans (Linnaeus 1758) into Northern Brazil, and its quick dispersion to practically the entire country, stimulated investigations on the arthropod community of cattle dung pats in pastures (Valério \& Guimarães 1983, Fava et al. 1994, Flechtmann et al. 1995a,b, Mendes \& Linhares 1999). Such community plays an important role in the dung pat decay process and in the natural control of dung breeding pests (MacQueen \& Beirne 1975, Merrit \& Anderson 1977, Roth et al. 1983, Anderson et al. 1984, Harris \& Blume 1986, Hanski 1987, Fay et al. 1990). Information on arthropod dung community is important not only to biological and integrated control programs, but also to the implementation of control programs of pests that breed in cattle droppings. However, there are very few studies published on this subject in Brazil, restricted to a few localities (Oliveira et al. 1993, Souza e Silva 1993, Flechtmann et al. 1995a,b, Mendes \& Linhares 1999). This paper presents data on diversity, abundance and seasonality of cattle dung breeding Diptera in the vicinity of São Carlos city, State of São Paulo, Southeastern Brazil.

\footnotetext{
Work supported by Fapesp, grants no. 91/3228-1 and 92/3434-3 ${ }^{+}$Corresponding author. Fax: +55-19-3289.3124. E-mail: aricio@unicamp.br

Received 23 February 2001

Accepted 16 August 2001
}

\section{MATERIALS AND METHODS}

The experimental sites were pastures of Brachiaria decumbens Saft. and Andropogon gayanus Kunth at Fazenda Canchim, a farm belonging to Empresa Brasileira de Pesquisa Agropecuária (Embrapa), located about $10 \mathrm{~km}$ northeast from São Carlos city. Ten naturally dropped cattle dung pats, approximately $24 \mathrm{~h}$ old, and the substract $5 \mathrm{~cm}$ underneath them were collected weekly during morning hours, placed in individual plastic containers and taken to the Entomology Laboratory of the Department of Parasitology, Campinas State University (Unicamp), about 150 $\mathrm{km}$ southeast of São Carlos. A total of 83 samples, yielding 830 pats, was collected from April 1992 to April 1993. In each sample, a quarter of four dung pats and the underlying substrate were placed into Berlese funnels to extract the Coleoptera and Macrochelidae mites, and the results will be published elsewhere. The remaining of the dung pats in the containers were covered with organza and kept at room temperature until the complete emergence of all Diptera. This procedure took approximately 30-40 days in the warm months and 40-50 days in the cooler months. Emerging Diptera and other arthropods were collected daily and placed in $70 \%$ alcohol for identification. The substract was then placed in water to extract, by flotation, any remaining viable pupa from which adults had not yet emerged. The collected pupae were kept in transparent gelatin capsules for adult emergence. Diptera identification were done using the identification keys of McAlpine (1981, 1987). The species were grouped into trophic groups following Valiela (1974) and Hanski (1987). To test for any correlation among family's abundances, the Pearson's correlation analysis was done using SAS ${ }^{\circledR}$ PROC CORR procedure (SAS 1987).

\section{RESULTS}

A total of 46,135 Diptera was obtained, belonging to 20 families and to at least 51 species. The most diverse and abundant families were Muscidae, Sepsidae, Sarcophagidae and Sphaeroceridae (Table). The oscillations in temperature and rainfall during the two experimental years determined a warm and humid period from October to March, and a cool and dry period from April to September (Fig. 1). When compared to the warm months, the emergence time during the cool period lasted 5 to 10 days longer. The 


\section{TABLE}

Diversity and abundance of cattle dung breeding Diptera emerged from dung pats naturally dropped at "Fazenda Canchim" pastures in São Carlos, Southeastern Brazil from April 1992 to April 1994

\begin{tabular}{lcrc}
\hline Species & Troffic group & Total & $\%$ \\
\hline Muscidae & & & \\
$\begin{array}{l}\text { Biopirellia bipuncta } \\
\text { Bitorachochaeta atricornis }\end{array}$ & LDBD & 1372 & 18.6 \\
Bitorachochaeta leucoprocta & & 9 & 0.1 \\
Brontaea debilis & PL & 6 & 0.1 \\
Brontaea sp. & PL & 1,886 & 39.2 \\
Cyrtoneurina geminata & LDBD & 1,277 & 19.7 \\
Cyrtoneurina rescita & LDBD & 27 & 17.3 \\
Haematobia irritans & SDBD & 4 & 0.4 \\
Morellia concacata & LDBD & 27 & 0.4 \\
Morellia paulistanensis & LDBD & 87 & 1.2 \\
Musca domestica & & 12 & 0.2 \\
Muscina stabulans & & 2 & 0.02 \\
Sarcopromusca pruna & LDBD & 109 & 1.5 \\
Stomoxys calcitrans & & 95 & 1.3 \\
Total & & 7,367 & 100 \\
\hline Anthomyidae
\end{tabular}

\begin{tabular}{llrc}
\hline $\begin{array}{l}\text { Anthomyiidae } \\
\text { Calythea sp. }\end{array}$ & LDBD & 1,183 & 100 \\
$\begin{array}{l}\text { Sarcophagidae } \\
\text { Chaetoravinia advena }\end{array}$ & LDBD & 268 & 7.0 \\
Hybopigia terminalis & LDBD & 4 & 0.1 \\
Hybopigia varia & LDBD & 184 & 4.9 \\
Lypoptilocnema crispula & LDBD & 1 & 0.02 \\
Oxysarcodexia avuncula & LDBD & 2,378 & 64 \\
Oxysarcodexia thornax & LDBD & 148 & 4 \\
Ravinia belforti & LDBD & 8 & 0.02 \\
Sarcophagula occidua & SDBD & 724 & 19.5 \\
\hline Total & & 3,715 & 100 \\
\hline
\end{tabular}

Calliphoridae

$\begin{array}{llll}\text { Phaenicia eximia } & \text { LDBD } & 1 & 100\end{array}$

Fanniidae

$\begin{array}{llll}\text { Fannia pusio } & \text { SDBD } & 18 & 85.7\end{array}$

$\begin{array}{llll}\text { Fannia sp. } & \text { SDBD } & 3 & 14.3\end{array}$

\begin{tabular}{lll}
\hline Total & 21 & 100
\end{tabular}

\begin{tabular}{|c|c|c|c|}
\hline $\begin{array}{l}\text { Dolichopodidae } \\
\text { Condylostylus sp. } \\
\text { Chrysotus sp. }\end{array}$ & PL & $\begin{array}{l}34 \\
72\end{array}$ & $\begin{array}{l}32 \\
68\end{array}$ \\
\hline Total & & 106 & 100 \\
\hline $\begin{array}{l}\text { Tipulidae } \\
\text { Teucolabis sp. } \\
\text { Limoniini } \mathrm{sp} .1\end{array}$ & SDBD & $\begin{array}{r}820 \\
1,567\end{array}$ & $\begin{array}{l}34.4 \\
65.6\end{array}$ \\
\hline Total & & 2,387 & 100 \\
\hline $\begin{array}{l}\text { Sepsidae } \\
\text { Archisepsis scabra (Loew) } \\
\text { Microsepsis furcata } \\
\quad \text { (Melander \& Spuler) }\end{array}$ & SDBD & $\begin{array}{l}2,834 \\
1,980\end{array}$ & $\begin{array}{r}10.3 \\
7.3\end{array}$ \\
\hline $\begin{array}{l}\text { Palaeosepsis insularis } \\
\text { (Williston) } \\
\text { Palaeosepsis pusio (Shiner) }\end{array}$ & & 12,870 & 47.3 \\
\hline Total & & 27,311 & 100 \\
\hline Sphaeroceridae & SDBD & & \\
\hline Coproica sp.? & & 1,390 & 61.9 \\
\hline Sphaerocera sp. & & 206 & 9.2 \\
\hline Leptocera sp.? & & 570 & 25.4 \\
\hline Other Sphaeroceridae (2 spp.) & & 80 & 3.5 \\
\hline Total & & 2,246 & 100 \\
\hline
\end{tabular}

cont.

\begin{tabular}{|c|c|c|c|}
\hline Species & Troffic group & Total & $\%$ \\
\hline Stratiomyidae & LDBD & & \\
\hline Microchrysa sp. & & 441 & 69.7 \\
\hline Sargus sp. & & 192 & 30.3 \\
\hline Total & & 633 & 100 \\
\hline Asilidae & PL & 37 & \\
\hline Bibionidae & PL & 1 & \\
\hline Cecidomyidae & - & 47 & \\
\hline Ceratopogonidae & PL & 37 & \\
\hline Chloropidae & SDBD & 22 & \\
\hline Mycetophilidae & SDBD & 5 & \\
\hline Phoridae & PL & 37 & \\
\hline Psychodidae & SDBD & 95 & \\
\hline Sciaridae & SDBD & 761 & \\
\hline Tachinidae & SDBD & 1 & \\
\hline Total Diptera & & 46,013 & \\
\hline
\end{tabular}

majority of the Diptera emerged within the first 20 days during the warm months and within the first 25 days in the dry period. The most abundant Diptera can be divided into three groups according to emergence time: (1) Sepsidae; Brontaea debilis, Calythea sp., Haematobia irritans (Muscidae); Sarcophagula occidua (Sarcophagidae) and part of the Sphaeroceridae that emerged during the first 10 days after the dung pats were collect from pastures; (2) the remaining Muscidae, Sarcophagidae and Sphaeroceridae that emerged between the 11th and the 20th days (3) Tipulidae, Sciaridae and Stratiomyidae that began to emerge after the 20th day. In general, the species presented greater abundance during the warm and humid period (Figs 2-5). The exceptions were Biopyrellia bipuncta (Fig. 2), Calythea sp. (Fig. 3) and Coproica sp. (Fig. 4) that were also abundant during the cold and dry period. The correlation coefficient was positive and significant for the most abundant families: Sepsidae vs. Sarcophagidae $(r=+0.56$; $p<0.0001)$; Sepsidae vs. Sphaeroceridae $(r=+0.53 ; p<0.0001)$; Muscidae vs. Sarcophagidae $(r=+0.73 ; p<0.0001)$.

\section{DISCUSSION}

As reported by other authors (Cervenka \& Moon 1991, Souza e Silva 1993), some loss of small sized specimens occurred, mainly during the extraction from the pats, but apparently, this fact did not influence the results, because of the great abundance of these insects in the samples. Although many authors state that Diptera species usually visit and lay eggs in dung pats within the first $24 \mathrm{~h}$ of dung exposition, results of Barth et al. (1994) indicate that low abundance or absence of some species would be the result of breeding preference by such species for older dung pats. In addition, some species of Sphaeroceridae and Sepsidae may have more than one generation in the dung pat (Laurence 1955, Souza e Silva 1993). The successional pattern of adult emergence was similar to that found by Nibaruta (1982) and Souza e Silva (1993). However, our results on emergence times differed from those of Nibaruta (1982). The low abundance of $H$. irritans may be attributed to the genetic resistance of the host, cattle breeding management procedures, and to its natural enemies found in the dung. The significant Muscidae and Sepsidae diversities were also recently verified in this country by 


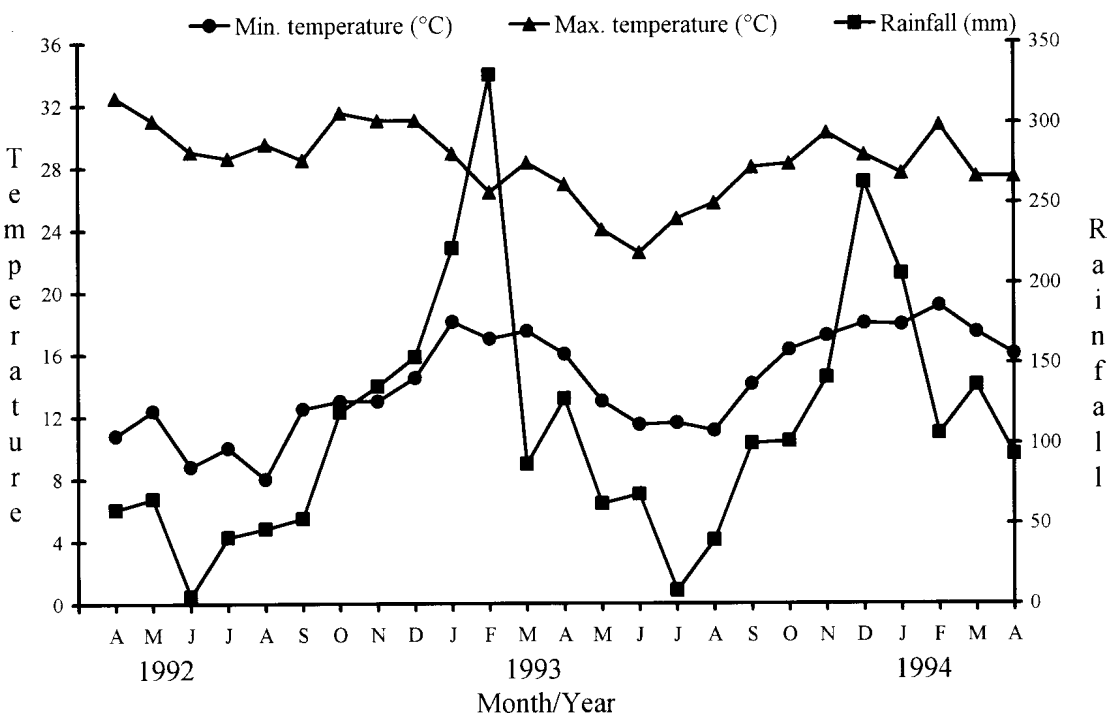

Fig. 1: monthly temperature and rainfall from April 1992 to April 1994 in São Carlos, São Paulo, Southeastern Brazil

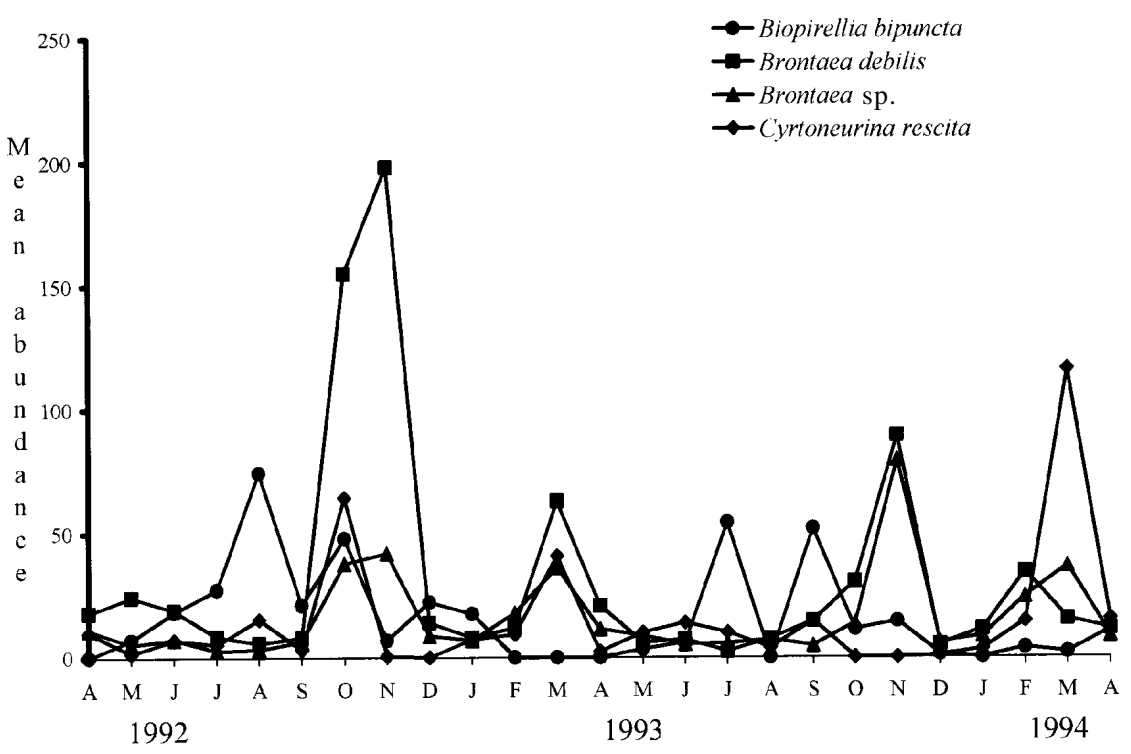

Month/Year

Fig. 2: seasonallity of B. bipuncta, B. debilis, Brontaea sp. and C. rescita, extracted from cattle manure collected at Fazenda Canchim pastures in São Carlos, São Paulo, Southeastern Brazil, from April 1992 to April 1994. Values are the average of two to four samples in each month.

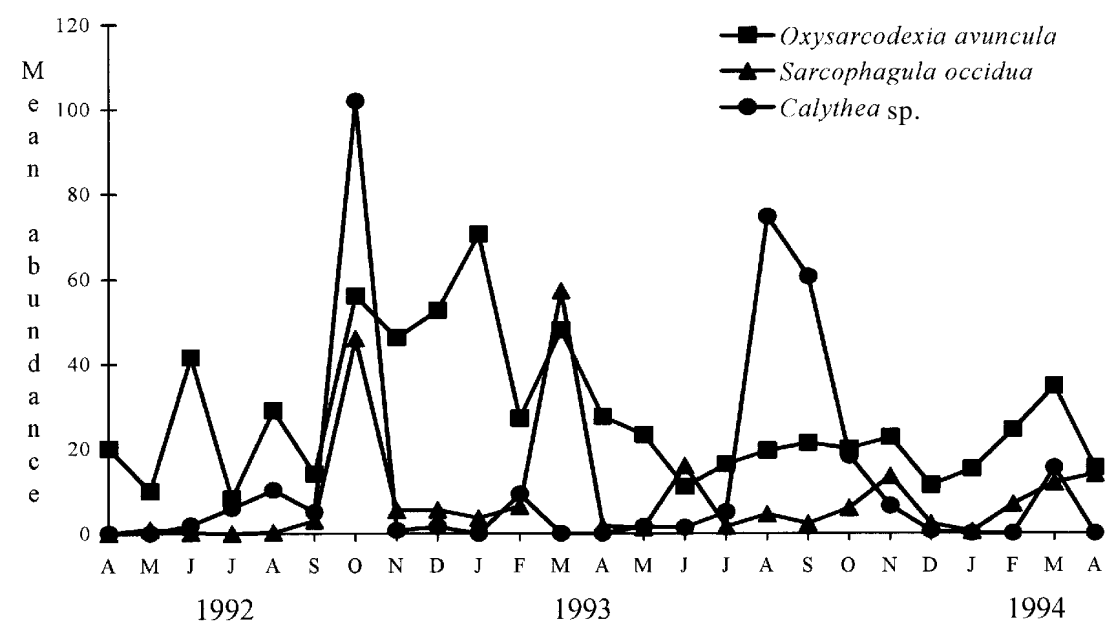

Month/Year

Fig. 3: seasonallity of O. avuncula, S. occidua and Calythea sp. extracted from cattle manure collected at Fazenda Canchim pastures in São Carlos, São Paulo, Southeastern Brazil, from April 1992 to April 1994. Values are the average of two to four samples in each month. 


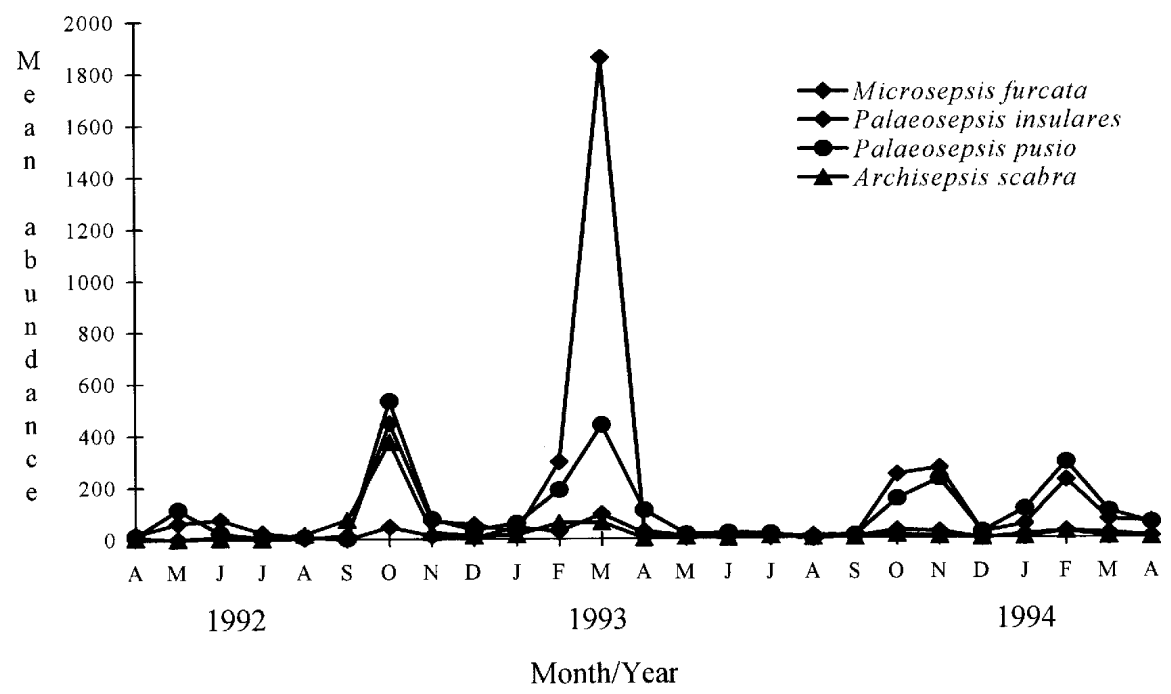

Fig. 4: seasonallity of M. furcata, P. insularis, P. pusio and A. scabra, extracted from cattle manure collected at Fazenda Canchim pastures in São Carlos, São Paulo, southeastern Brazil, from April 1992 to April 1994. Values are the average of two to four samples in each month.

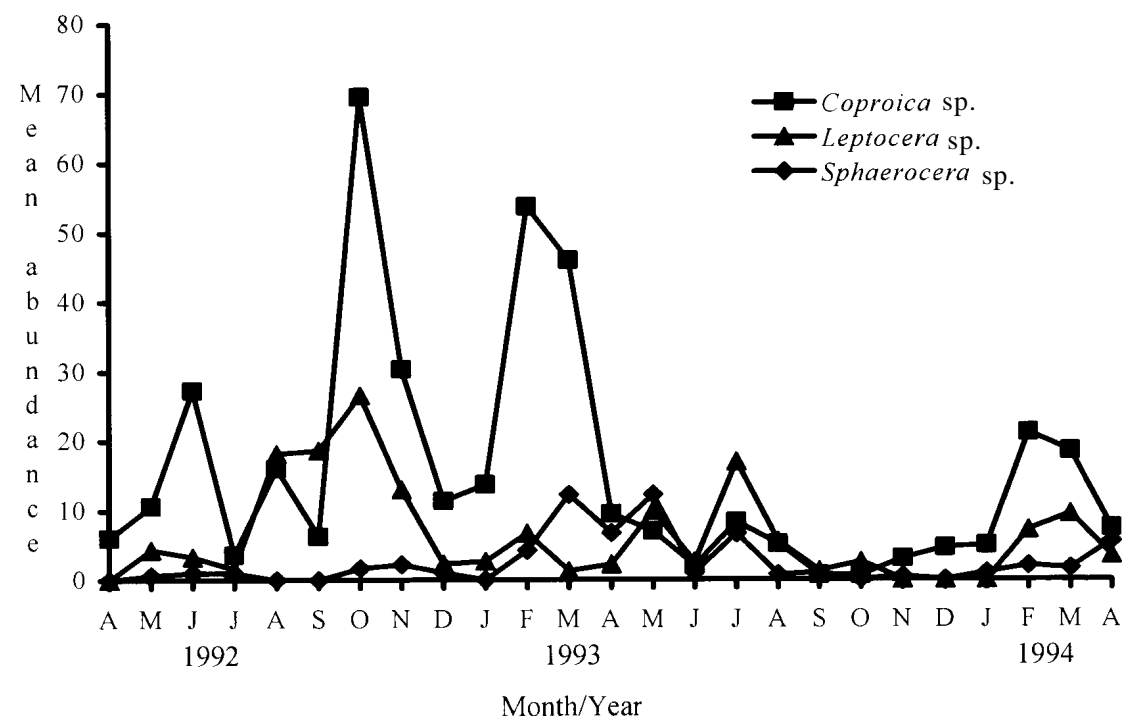

Fig. 5: seasonallity of Coproica sp., Leptocera sp. and Sphaerocera sp., extracted from cattle manure collected at Fazenda Canchim pastures in São Carlos, São Paulo, Southeastern Brazil, from April 1992 to April 1994. Values are the average of two to four samples in each month.

Oliveira et al. (1993), Souza e Silva (1993), and Flechtmann et al. (1995). Although the Sepsidae are generally abundant, they are not considered to be important $H$. irritans competitors or dung decaying agents. Their larvae are considered dung tunnelers, contributing to pat aeration, which can help dung colonization by other arthropods, and to dung loss of water. Therefore, they aid in the natural control of $H$. irritans. The correlation analysis suggests that the observed abundances of Sarcophagidae and Brontaea spp. may be enough to promote a statistically significant reduction in the abundances of other analyzed groups. Larvae of these two groups are known to be facultative predators in some situations (Harris \& Blume 1986, Ferrar 1987, Hanski 1987). It is also important to point out the possibility that some adults of Diptera may act as transporters of Dermatobia hominis (Diptera: Cuterebridae) eggs (Artigas \& Serra 1965, Oliveira 1986).

\section{ACKNOWLDGEMENTS}

Diptera identification was done partly with the help of Dr Denise Pamplona, Dr Marcia Souto Couri and Dr Rita Tibana from Museu Nacional do Rio de Janeiro.

\section{REFERENCES}

Anderson JR, Merrit RW, Loomis EC 1984. The insect-free cattle dung fouling of rangeland pastures. J Econ Entomol 77: 133141.

Artigas PT, Serra RG 1965. Portadores de ovos de Dermatobia hominis (L. Jr., 1781). Atualização da lista de foréticos, com a enumeração de novos agentes transmissores do "berne". Ciên Cult 17: 21-29.

Barth D, Karrer M, Heinze-Mustz EM, Elster N 1994. Colonization and degradation of cattle, dung: aspects of sampling, fecal composition, and artificially formed pats. Environ Entomol 23: 571-578.

Blume RR 1985. A checklist, distributional record, and annotated bibliography of the insects associated with bovine drop- 
pings on pastures in America north of Mexico. Southwest Entomol 9: 1-55.

Cervenka VJ, Moon RD 1991. Arthropods associated with cattle dung pats in Minnesota. J Kansas Ent Soc 64: 131-143.

Fava ALB, Souza AM, Lomônaco C 1994. Estrutura fisiológica e distribuição espacial de Haematobia irritans (L.) (Diptera: Muscidae). An Soc Entomol Brasil 23: 63-70.

Fay HAC, MacQueen A, Doube BM 1990. Impact of fauna on mortality and size of Haematobia spp. (Diptera; Muscidae) in natural dung pats in Australia and South Africa. Bull Entomol Res 80: 385-392.

Ferrar P 1987. A Guide to the Breeding Habits and Immature Stages of Diptera Cyclorrhapha, Part. I, Entomonograph vol. 8, Scandinavian Science Press, Leiden, 478 pp.

Flechtmann CAH, Rodrigues SR, Couto HTZ 1995a. Controle biológico da mosca-dos-chifres (Haematobia irritans irritans) em Selvíria, Mato Grosso do Sul. 3. Levantamento de espécies fimícolas associadas à mosca. Revta Bras Ent 39: 249-258.

Flechtmann CAH, Rodrigues SR, Araújo SD, Wenzel RL 1995b. Levantamento de insetos fimícolos em Ilha Solteira, São Paulo, Brasil. Revta Bras Ent 39: 115-120.

Hanski I 1987. Nutritional ecology of dung- and carrion-feeding insects. In F Slaniki Jr, JG Rodrigues (eds), Nutritional Ecology of Insects, Mites, Spiders and Related Invertebrates, John Wiley, New York, p. 837-883.

Harris RL, Blume RR 1986. Beneficial arthropods inhabiting bovine droppings in the United States. In RS Patterson, DA Rutz (eds), Biological Control of Muscoid Flies, Miscellaneous Publications of the Ent Soc Am 62, p. 10-15.

Lancaster JL, Meisch MV 1986. Haematobia irritans (Linneaus), the horn fly. In JL Lancaster, MV Meisch (eds), Arthropods in Livestock and Poultry Production, John Wiley, New York, p. 94-103.

Laurence BR 1955. The larval inhabitants of cow pats. J Anim Ecol 23: 234-260.

MacQueen A, Beirne B 1975. Influence of other insects on production of horn fly, Haematobia irritans (Diptera; Muscidae), from cattle dung in South-Central British Columbia. Can Entomol 107: 1255-1264.

McAlpine JE. 1981. Manual of Nearctic Diptera, Vol. I, Re- search Branch Agriculture Canada, Quebec, 674 pp.

McAlpine JE. 1987. Manual of Nearctic Diptera, Vol. II, Research Branch Agriculture Canada, Quebec, p. 675-1332.

Mendes J, Linhares AX. 1999. Diapause, pupation sites and parasitism of the horn fly, Haematobia irritans, in southeastern Brazil. Med Vet Entomol 13: 185-190.

Merrit RW, Anderson JR 1977. The effects of different pasture and rangeland ecosystems on the annual dynamics of insects in cattle droppings. Hilgardia 45: 31-71.

Nibaruta G 1982. Étude écologique des diptéres associés aux excréments de la vache domestique em milieu tempéré. Rev Ecol Biol Sol 19: 203-223.

Oliveira GP 1986. Distribuição sazonal de dípteros muscóides sinantrópicos, simbovinos e foréticos de Dermatobia hominis L. Jr. em São Carlos, Estado de São Paulo: I. Estábulo. Arq Biol Tecnol 29: 311-325.

Oliveira GP, Mendes J, Dutra SAH. 1993. Abundância relativa da entomofauna simbovina na região de São Carlos, São Paulo. Ocorrência das principais espécies. Anais $45^{\text {a }}$ Reunião Anual da SBPC, Recife, p. 946.

Poorbaugh JH, Anderson JR, Burguer JF 1968. The insects inhabitants of undisturbed cattle droppings in Northern California. California Vector Views 15: 17-36.

Roth JP, Finscher GT, Summerlin JW 1983. Competition and predation as mortality factors of the horn fly, Haematobia irritans (L) (Diptera; Muscidae), in a central Texas pasture habitat. Environ Entomol 12: 106-109.

SAS Institute Inc. 1987. SAS User's Guide: Statistics, 6th ed., Cary, North Carolina, 1028 pp.

Souza e Silva SM. 1993. Distribuição Sazonal e Abundância Relativa de Dípteros Simbovinos na Região de Itu, SP, MSc Thesis, Universidade Estadual de Campinas, Campinas, 71 pp.

Valério JR, Guimarães JH 1983. Sobre a ocorrência de uma nova praga, Haematobia irritans (L) (Diptera: Muscidae), no Brasil. Revta Bras Zool 1: 417-418.

Valiela I 1974. Composition of food webs and population limitation on dung arthropod communities during invasion and succession. Amer Midl Nat 92: 370-385. 
